Article

\title{
The Chemical Composition of Biogas Digestates Determines Their Effect on Soil Microbial Activity
}

\author{
Kerstin Nielsen ${ }^{1}$, Christina-Luise Roß ${ }^{2, *}{ }^{\mathbb{C}}$, Marieke Hoffmann ${ }^{3}$, Andreas Muskolus ${ }^{1}$, \\ Frank Ellmer ${ }^{2}$ and Timo Kautz ${ }^{2}$ \\ 1 Institute for Agricultural and Urban Ecological Projects affiliated to Berlin Humboldt University, \\ Philippstraße 13, 10115 Berlin, Germany; kerstin.nielsen@iasp.hu-berlin.de (K.N.); \\ andreas.muskolus@iasp.hu-berlin.de (A.M.) \\ 2 Albrecht Daniel Thaer-Institute of Agricultural and Horticultural Sciences, Faculty of Life Sciences, Berlin \\ Humboldt University, Invalidenstraße 42, 10115 Berlin, Germany; frank.ellmer@agrar.hu-berlin.de (F.E.); \\ timo.kautz@agrar.hu-berlin.de (T.K.) \\ 3 Deutsche Umwelthilfe E.V., Hackescher Markt 4, 10178 Berlin, Germany; hoffmann@duh.de \\ * Correspondence: roschris@agrar.hu-berlin.de
}

Received: 5 June 2020; Accepted: 22 June 2020; Published: 24 June 2020

\begin{abstract}
Digestates are commonly used as organic inputs in agriculture. This study aimed to answer four questions: (1) What are the immediate and longer-term impacts of digestates on soil microbial activity?; (2) How much of the digestates' carbon is mineralized within the first months? (3) How do the nitrogen, lignin, cellulose, and hemicellulose contents of digestates influence microbial activity and carbon mineralization? (4) How does the soil type influence mineralization? To investigate this, dehydrogenase activity (DHA) was measured in a field trial and in laboratory experiments with five digestates (DGs), cattle slurry, and cattle manure. DHA measurements were supplemented with soil respiration experiments using two different soils. DHA was significantly increased by all organic inputs, but decreased back to the control level within seven months under field conditions. Twenty percent to $44 \%$ of the organic carbon $\left(\mathrm{C}_{\mathrm{org}}\right)$ in the digestates was converted to $\mathrm{CO}_{2}$ after 178 days. Soil respiration was significantly negatively correlated to lignin content $(\mathrm{r}=-0.82, p<0.01)$ and not correlated to nitrogen, cellulose, or hemicellulose content. On the basis of equal carbon application, slurry promoted soil respiration and DHA more strongly than digestates in the short term.
\end{abstract}

Keywords: dehydrogenase activity; soil respiration; separation; biogas residues; digestates

\section{Introduction}

As a result of growing numbers of biogas plants in the EU, more digestates are produced and applied on arable land [1]. These digestates' compositions and chemical properties differ significantly depending on the substrates, process temperature, retention time, etc., of the biogas plant $[2,3]$. The increase in energy production from purpose-grown phytomass has led to concerns regarding the impact of the vast amounts of residues that are consequently incorporated in agricultural fields, because some authors report a declining effect of such residues on soil fertility [4]. Arguments to this regard are, for example, that separated solid digestates may not contain sufficient amounts of nutrients to be referred to as fertilizers at all and that digestates in general may not be easily degradable enough to provide soil microorganisms with energy for their metabolisms [5]. If digestate application would indeed reduce soil fertility, this would be especially worrisome since recent studies have already shown that the overall EU agricultural productivity is slowing down and lagging behind international competitors [6].

Several studies tried to examine the effects of digestate application on soil microbial activity. Abubaker et al. [7] and Odlare et al. [8] reported increased nitrogen mineralization capacity and 
potential ammonium oxidation rates after the application of biogas digestates, while Abubaker et al. [9] showed that microbial activity after digestate application was comparable to that after cattle slurry application. The experiments of Hupfauf et al. [10] showed that microbial basal respiration and metabolic quotient were higher with digestates than with untreated slurry or mineral fertilization. The comparison of biogas digestates and fly ash also showed the beneficial effects of digestates on soil microbial activity and biomass $[11,12]$. But even though those results suggest a positive impact on microbial activity, some also indicate a potential inhibitory effect $[13,14]$ or report only a short-lived rise in microbial activity, followed by a drop to initial levels $[15,16]$. Furthermore, most of these studies have only a limited explanatory power because they were either done with a very limited number of digestates and/or only under controlled conditions. Abubaker et al. [9] and Johansen et al. [16], for example, used only two digestates and cattle slurry and Odlare et al. [8] and García-Sánchez et al. [11] each used only one digestate in their experiments. The investigations of Abubaker et al. [7] and Garcia-Sanchez et al. [12] were carried out as pot experiments. Other experiments took place in plastic trays or small containers in incubation chambers [9,15]. Furthermore, many investigations only spanned a rather short amount of time. The experiments of Risberg et al. [14], for example, lasted for 12 days, those of de la Fuente et al. [15] 56 days, and those of Johansen et al. [16] 9 days.

In arable soils, organic manures are a relevant source for the reproduction of organic matter [17]. Most probably, the contribution of digestates to the storage of soil organic matter depends on the substrate inputs, which is also supported by modeling based on results from incubation experiments [18]. However, the number of investigations using field experiments is very limited and, again, these studies often focus on very brief periods after application and on a very small number of different digestates [19]. One aim of this work was, therefore, to investigate the effect of digestates on microbial activity up to 5 years after application under field and controlled conditions.

Microbial activity is directly linked to the mineralization of the organic matter applied with the digestates or other organic fertilizers. While nutrient availability, and thus the fertilizing effects of digestates, have been studied comprehensively by several authors $[3,20]$, decomposition processes and the fate of the digestates' carbon in soils remain somewhat unclear [21,22]. Some authors claim that digestates help little to reproduce soil organic matter (SOM) contents in soil because they are rapidly mineralized, produce high $\mathrm{CO}_{2}$ exhalation rates from soil, and provide only small amounts of stable carbon $[15,23]$. Others report that carbon contents in soil were significantly elevated after digestate application, suggesting a positive effect on soil organic matter [12]. The second goal of this study was, therefore, to gain some knowledge about the mineralization rate of the carbon that is applied when digestates are used as fertilizers.

In order to investigate microbial activity and carbon mineralization, measurements of dehydrogenase activity (DHA) were used in a field experiment, in which five different digestates, cattle slurry, and cattle manure have been used as fertilizers for several years, and in related laboratory experiments, where the same organic substrates were tested as in the field trial. These DHA measurements were supplemented with soil respiration experiments with an exceptionally long duration of 178 days. These two methods were chosen for the following reasons:

The first stages of organic matter degradation in soil include the reduction in particle size and the rapid transformation of easily degradable fractions by soil organisms. Dehydrogenases play an important role in the degradation by transferring hydrogen and electrons from organic substrates to inorganic acceptors [24]. They are very sensitive and react quickly to environmental factors, like the introduction of chemical compounds, changes in moisture, $\mathrm{pH}$ value, and temperature, or the availability of oxygen [24,25]. Dehydrogenases occur intracellularly in all living microbes, but do not accumulate in the soil outside of microorganisms [25]. Measuring the dehydrogenase activity does not provide detailed information about the functional diversity of the microbiome, but allows the determination of the metabolic activity of soil microorganisms in response to cultivation measures [25,26]. 
During the degradation process, $\mathrm{CO}_{2}$ and inorganic compounds, such as ammonium, phosphate, and sulfate are released, while poorly degradable or stabilized organic compounds accumulate in the soil [27]. Soil respiration, i.e., the release of $\mathrm{CO}_{2}$ from soils, can be measured in order to assess the microbiological activity of the soil, the effect of organic fertilizers thereon, and their influence on SOM reproduction [28]. In the field, however, this is elaborate and complicated because microbial respiration depends on various factors, like the physiological state of the microorganisms, the moisture and structure of the soil, the temperature, and the nutrient supply, and is therefore subject to seasonal and daily fluctuations $[29,30]$. In addition to microorganisms, the soil macro fauna and plant roots also contribute to $\mathrm{CO}_{2}$ release, which requires corresponding mathematic corrections [29-31]. Incubation experiments in the laboratory, on the other hand, allow the sole measurement of the $\mathrm{CO}_{2}$ release caused by microbial degradation [29]. Differences in the degradability of organic materials can be determined, as well as the possible toxic effects of test substrates [30]. The effects of organic fertilizers on soil respiration and SOM reproduction performance are determined by their content of organic carbon and by the respective degradation stability of the organic substance in the products. Degradation stability is influenced by the chemical composition of the substrates, the cellulose, hemicellulose and lignin content, and the particle size and incrustation in the lignocellulose complex of the organic matter $[32,33]$. In particular, lignin is usually rather difficult to metabolize for most soil organisms [30,34].

Anaerobic digestion largely stabilizes the organic matter through microbial degradation. The amount of readily available carbon in digestates is therefore proportionately low, while stable compounds, such as lignin, are relatively high [35].

It is well known that the soil texture and the chemical and physical properties related to it influence the composition of the microbial community and its ability to degrade organic materials. A higher clay content may, for example, protect organic carbon compounds against microbial degradation [36,37]. On the other hand, there are reports that labile $\mathrm{C}$ inputs from digestates may promote denitrification in fine-textured soils [38].

Based on the knowledge generated from the literature, we addressed three hypotheses: (1) Dehydrogenase activity and soil respiration will be restricted when digestates with high lignin contents are applied compared to digestates or other organic fertilizers with lower lignin contents; (2) The repeated application of digestates over many years will have a lasting effect on microbial activity in the soil that can be seen independently of acute application; (3) A soil with a higher clay content will result in a lower soil respiration after the application of organic fertilizers than a soil with a lower clay content.

\section{Materials and Methods}

Both DHA soil respiration measurements were either carried out in or based on an existing field trial and its treatments. Therefore, the structure of the field experiment is explained first in the following text section. The description of the DHA measurement and the soil respiration follow in Sections 2.2 and 2.3 .

\subsection{Field Experiment}

In the field experiment, five different digestates, cattle manure, and cattle slurry are used as organic fertilizers. The experimental site was the research station of the Institute of Agricultural and Urban Ecological Projects (IASP) $25 \mathrm{~km}$ west of Berlin, Germany. The soil on this site is a sandy, slightly loamy luvisol with an average $\mathrm{C}_{\text {org }}$ content of $0.7 \%$, a medium $\mathrm{P}$ and $\mathrm{K}$ content (extracted with

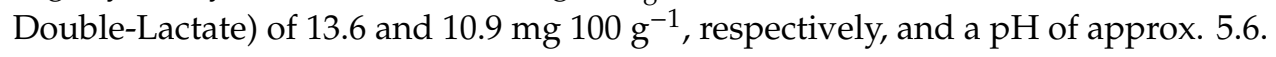

The field trial was started in 2011 and consists of a one-factorial randomized block system with four replications. The crop rotation is: Winter rye as whole crop silage-maize-winter rye as whole crop silage-sorghum. Fertilizers are applied twice a year before the sowing of rye or maize/sorghum. In addition to the organic fertilizers, there is also an unfertilized control and one treatment receiving only mineral fertilizer (calcium ammonium nitrate (CAN)). 
The fertilizer quantities are based on the carbon content of a standard manure application of $12.5 \mathrm{tha}^{-1} \mathrm{a}^{-1}$. The amount is split in two doses $\left(7.5 \mathrm{tha}^{-1}\right.$ before maize or sorghum and $5 \mathrm{tha}^{-1}$ before winter rye). The amount of the other organic fertilizers is based on the amount of organic carbon spread by the manure at every application date, so that the amount of $\mathrm{C}_{\text {org }}$ is the same for all applied fertilizers. The resulting differences in applied nitrogen are balanced via mineral fertilization with CAN. Average inputs and operating parameters of the biogas plants providing the digestates are given in Table 1.

Plant D uses the liquid-/solid-separation of the digestate as a subsequent treatment. Therefore, five products are obtained from the four plants. The cattle slurry that serves as a substrate in plant A is used as a reference treatment in the field trial.

Table 2 gives an overview over the total amounts of applied organic fertilizers, and of the amounts of carbon, nitrogen, phosphorus, and potassium for the two application dates directly related to the measurement period of dehydrogenase activity and the average of spring and autumn applications over the years.

DHA measurements were carried out in 2016 after five years of continued fertilizer application. Weather condition data for the years of the measurements and long-term reference data (Figure 1) were obtained from a station of the German Meteorological Service, which is located next to the experimental field.

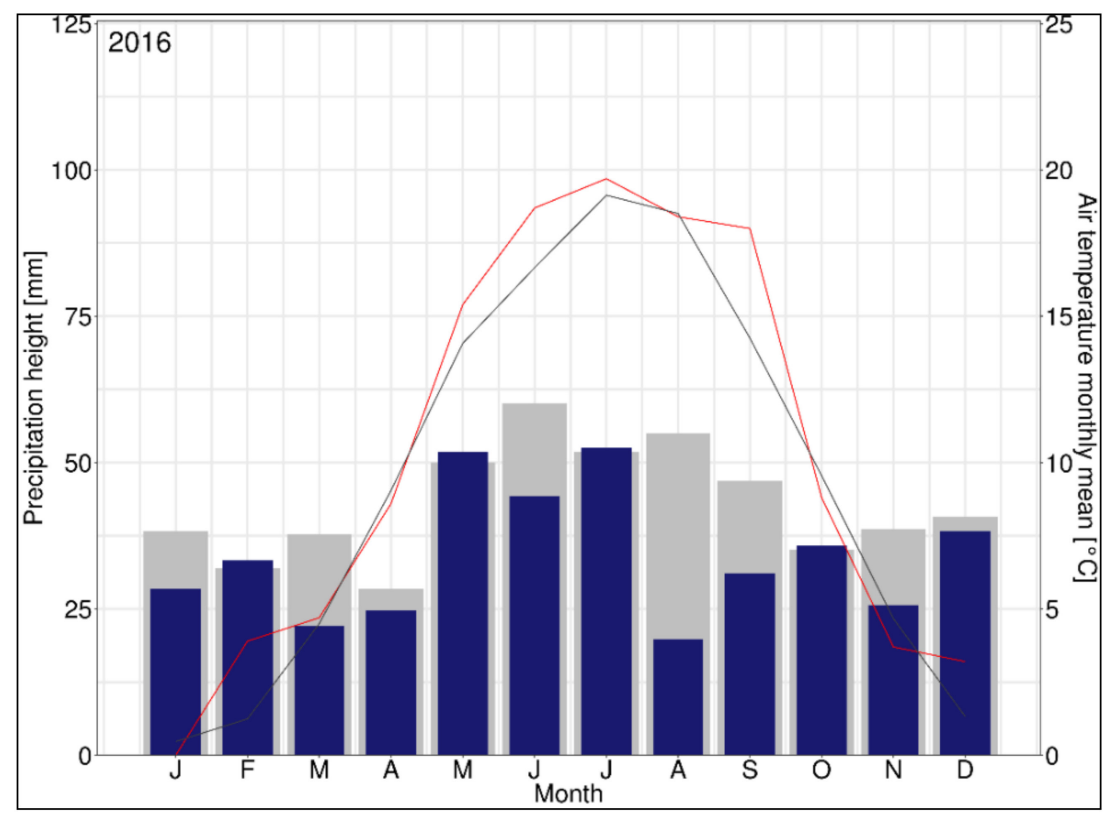

Figure 1. Precipitation heights (blue bars) and medium monthly air temperature (red line) of 2016 on the experimental site. Gray bars and the black line show the medium long-term values (1981-2010). 
Table 1. Input materials and operating parameters of the four biogas plants included in the study (percent in fresh matter (FM)).

\begin{tabular}{|c|c|c|c|c|c|c|c|c|}
\hline Plant & \multirow{3}{*}{$49 \%$} & A & \multicolumn{2}{|c|}{ B } & \multicolumn{2}{|r|}{$\mathrm{C}$} & \multicolumn{2}{|c|}{ D } \\
\hline \multirow{6}{*}{ Average Input } & & cattle slurry & \multirow{2}{*}{$43 \%$} & \multirow{2}{*}{ pig slurry } & \multirow{6}{*}{$\begin{array}{l}86 \% \\
14 \%\end{array}$} & \multirow{6}{*}{$\begin{array}{c}\text { corn silage } \\
\text { rye and rye } \\
\text { silage }\end{array}$} & $31 \%$ & cattle slurry \\
\hline & & & & & & & $24 \%$ & grass silage \\
\hline & $34 \%$ & corn silage & $46 \%$ & corn silage & & & $20 \%$ & corn silage \\
\hline & $11 \%$ & grass silage & $6 \%$ & $\begin{array}{l}\text { millet } \\
\text { silage }\end{array}$ & & & $16 \%$ & cattle manure \\
\hline & $3 \%$ & triticale silage & $4 \%$ & $\begin{array}{l}\text { grass } \\
\text { silage }\end{array}$ & & & \multirow[t]{2}{*}{$9 \%$} & \multirow[t]{2}{*}{ rye silage } \\
\hline & $3 \%$ & fodder remains & $1 \%$ & $\begin{array}{l}\text { fodder } \\
\text { remains }\end{array}$ & & & & \\
\hline Operating temperature & \multicolumn{2}{|r|}{ mesophile } & \multirow{2}{*}{\multicolumn{2}{|c|}{$\begin{array}{l}\text { mesophile } \\
60 \text { days }\end{array}$}} & \multirow{2}{*}{\multicolumn{2}{|c|}{$\begin{array}{l}\text { thermophile } \\
50 \text { days }\end{array}$}} & \multicolumn{2}{|c|}{ mesophile } \\
\hline Retention time & \multicolumn{2}{|r|}{70 days } & & & & & \multirow{2}{*}{\multicolumn{2}{|c|}{$\begin{array}{c}80 \text { days } \\
\text { "DG Mix liquid" and } \\
\text { "DG Mix solid" }\end{array}$}} \\
\hline Related products & & $\begin{array}{l}\text { "DG cattle" and } \\
\text { "Cattle Slurry" }\end{array}$ & \multicolumn{2}{|c|}{ "DG Pig" } & \multicolumn{2}{|c|}{ “DG Renew" } & & \\
\hline
\end{tabular}


Table 2. Total amounts of organic fertilizers applied in the field trial and of the carbon, nitrogen, phosphorus, and potassium applied with them between spring 2011 and autumn 2016.

\begin{tabular}{|c|c|c|c|c|c|c|c|c|}
\hline Applied Amount of & Application Date & DG Cattle & DG Pig & DG Renew & DG Mix Solid & DG Mix Liquid & Cattle Slurry & Cattle Manure \\
\hline \multirow{4}{*}{$\begin{array}{l}\text { Organic fertilizer } \\
\qquad\left(\mathrm{t} \mathrm{ha}^{-1} \mathrm{FM}\right)\end{array}$} & Average Spring & 24.9 & 37.6 & 15.7 & 6.8 & 26.8 & 19.3 & 7.5 \\
\hline & Average Autumn & 17.2 & 23.8 & 13 & 4.9 & 23.9 & 15 & 5 \\
\hline & 10/2015 (to rye) & 14.3 & 15.1 & 12.5 & 4.2 & 20.2 & 13.3 & 5 \\
\hline & 5/2016 (to sorghum) & 28.8 & 23.9 & 15.3 & 6.8 & 32.5 & 23.6 & 7.5 \\
\hline \multirow{4}{*}{$\begin{array}{c}\mathrm{C}_{\mathrm{org}} \\
\left(\mathrm{t} \mathrm{ha}^{-1}\right)\end{array}$} & Average Spring & \multirow{4}{*}{\multicolumn{7}{|c|}{$\begin{array}{l}0.6 \text {; same amount for all } \\
0.5 \text {; same amount for all } \\
0.4 \text {; same amount for all } \\
0.7 \text {; same amount for all }\end{array}$}} \\
\hline & Average Autumn & & & & & & & \\
\hline & 10/2015 (to rye) & & & & & & & \\
\hline & 5/2016 (to sorghum) & & & & & & & \\
\hline \multirow{4}{*}{$\begin{array}{l}\mathrm{N} \text { from organic } \\
\text { fertilization } \\
\left(\mathrm{kg} \mathrm{ha}^{-1}\right)\end{array}$} & Average Spring & 109 & 117.9 & 90.6 & 36.8 & 118.1 & 62.8 & 48.7 \\
\hline & Average Autumn & 72.8 & 79 & 75.4 & 26.8 & 108.9 & 46.4 & 40.5 \\
\hline & $10 / 2015$ (to rye) & 57.6 & 61.2 & 68 & 22.2 & 68.4 & 37.8 & 30.8 \\
\hline & 5/2016 (to sorghum) & 124.5 & 108.0 & 88.4 & 36.6 & 124 & 68.4 & 62.3 \\
\hline \multirow{4}{*}{$\begin{array}{l}\mathrm{N} \text { from balancing } \\
\text { mineral fertilization } \\
\left(\mathrm{kg} \mathrm{ha}^{-1}\right)\end{array}$} & Average Spring & 21.5 & 12.6 & 39.9 & 94 & 4.1 & 67.7 & 81.9 \\
\hline & Average Autumn & 36.1 & 29.9 & 33.6 & 82.2 & 0 & 62.5 & 68.5 \\
\hline & 10/2015 (to rye) & 10.8 & 7.2 & 0.4 & 46.2 & 0 & 30.6 & 37.6 \\
\hline & 5/2016 (to sorghum) & 0 & 16.4 & 36.1 & 87.9 & 0.5 & 56 & 62.2 \\
\hline \multirow{4}{*}{$\begin{array}{c}\mathrm{N}_{\text {total }} \\
\left(\mathrm{kg} \mathrm{ha}^{-1}\right)\end{array}$} & Average Spring & \multirow{4}{*}{\multicolumn{7}{|c|}{$\begin{array}{l}\text { 130.5; same amount for all } \\
\text { 109; same amount for all } \\
\text { 68.4; same amount for all } \\
\text { 124.5; same amount for all }\end{array}$}} \\
\hline & Average Autumn & & & & & & & \\
\hline & 10/2015 (to rye) & & & & & & & \\
\hline & 5/2016 (to sorghum) & & & & & & & \\
\hline \multirow{4}{*}{$\mathrm{K}\left(\mathrm{kg} \mathrm{ha}^{-1}\right)$} & Average Spring & 74.7 & 71.7 & 78.3 & 29.3 & 104.5 & 47 & 46.4 \\
\hline & Average Autumn & 42.9 & 59 & 52.9 & 31.1 & 81.3 & 45.3 & 43.1 \\
\hline & 10/2015 (to rye) & 44 & 44.2 & 74.6 & 14.9 & 74 & 28.3 & 23.1 \\
\hline & 5/2016 (to sorghum) & 107.2 & 81 & 82.3 & 31.8 & 118 & 58 & 56.1 \\
\hline \multirow{4}{*}{$\mathrm{P}\left(\mathrm{kg} \mathrm{ha}^{-1}\right)$} & Average Spring & 17.8 & 18.0 & 15.2 & 10.7 & 19.2 & 12.3 & 9.5 \\
\hline & Average Autumn & 11.2 & 17.6 & 9.8 & 8.2 & 12.7 & 10.9 & 12.3 \\
\hline & 10/2015 (to rye) & 11.7 & 16.3 & 9.7 & 5.2 & 12.9 & 9.6 & 7.4 \\
\hline & 5/2016 (to sorghum) & 22.4 & 36.0 & 17.8 & 12.6 & 21.0 & 15.2 & 12.0 \\
\hline
\end{tabular}




\subsection{Dehydrogenase Activity (DHA)}

Dehydrogenase activity was measured using 2,3,5-Triphenyltetrazoliumchlorid (TTC) according to DIN EN ISO 23753-1 [39]. During this standard procedure, a TTC solution is added to the soil or a soil-substrate mixture and incubated at $25{ }^{\circ} \mathrm{C}$ for $16 \mathrm{~h}$. As a result of dehydrogenase activity, triphenylformazan (TPF) is released, which can be extracted with acetone and measured photometrically at a wavelength of $485 \mathrm{~nm}$.

The measurements in the field trial took place on seven dates in 2016, starting shortly before fertilization and continuing until after the harvest of sorghum. Figure 2 provides an overview of the sample dates, as well of the sowing and harvesting dates and the dates of fertilizer application in the year before the sampling and in 2016. Soil samples were taken according to DIN ISO 10381-1:2003-08 [40] from the top $20 \mathrm{~cm}$ as mixed samples from several points per plot with a boring rod.

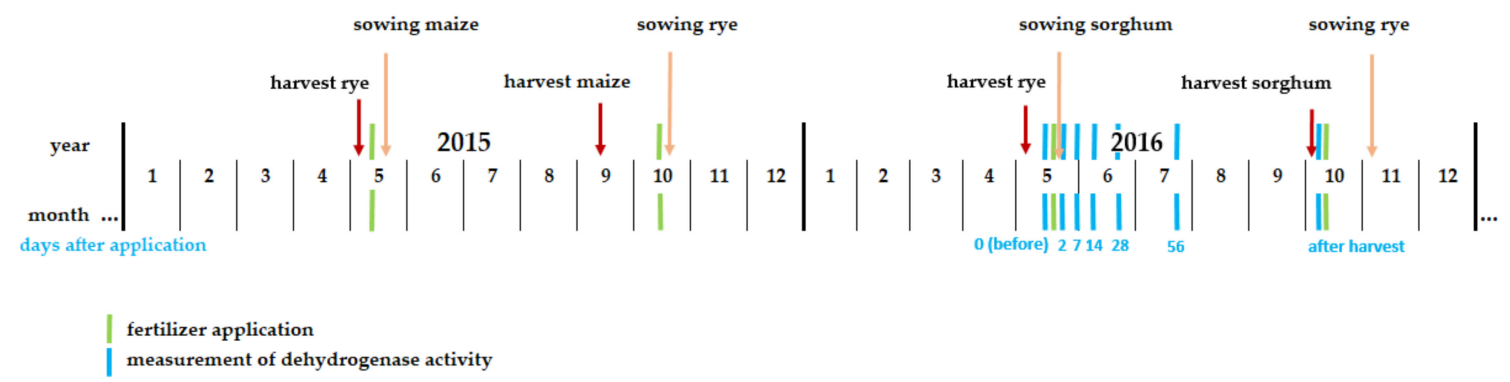

Figure 2. Dates of sowing, harvest, fertilizer application, and dehydrogenase activity measurements in the field trial in 2015 and 2016.

Dehydrogenase activity was also measured under controlled conditions in the laboratory. Soil from the unfertilized plots in the field trial was used for the measurements. The soil was mixed with the same organic fertilizers used in the field trial and incubated at $20^{\circ} \mathrm{C}$ and $60 \%$ maximum water-holding capacity $\left(\mathrm{WHC}_{\max }\right)$. Different amounts of water applied with the fertilizers were equalized accordingly. Two different setups were installed where substrates were applied to vessels holding $40 \mathrm{~g}$ dried soil in an amount corresponding to: (a) $0.009 \mathrm{~g} \mathrm{~N}$ per vessel or (b) $0.08 \mathrm{~g} \mathrm{C}_{\text {org }}$ per vessel. Treatments with wheat straw and mineral fertilizer (calcium ammonium nitrate; $C A N$ ) were included in the experiment, as well as a soil only control. Wheat straw was included in the C-based setup, CAN in the N-based one. Measurements were then taken according to DIN EN ISO 23753-1 at the same intervals as in the field trial (before and 2, 7, 14, 28, and 56 days after application). All treatments were replicated three times. Chemical parameters of the organic fertilizers used for the dehydrogenase measurements in the laboratory are given in Table 3, texture and chemical parameters of the soil are given in Table 4 (soil from Berge). The same batch of organic fertilizers was used for the soil respiration measurements described below.

Table 3. Selected chemical parameters of the substrates used for the dehydrogenase measurements in the laboratory and for the soil respiration experiment. "n.d." = not determined.

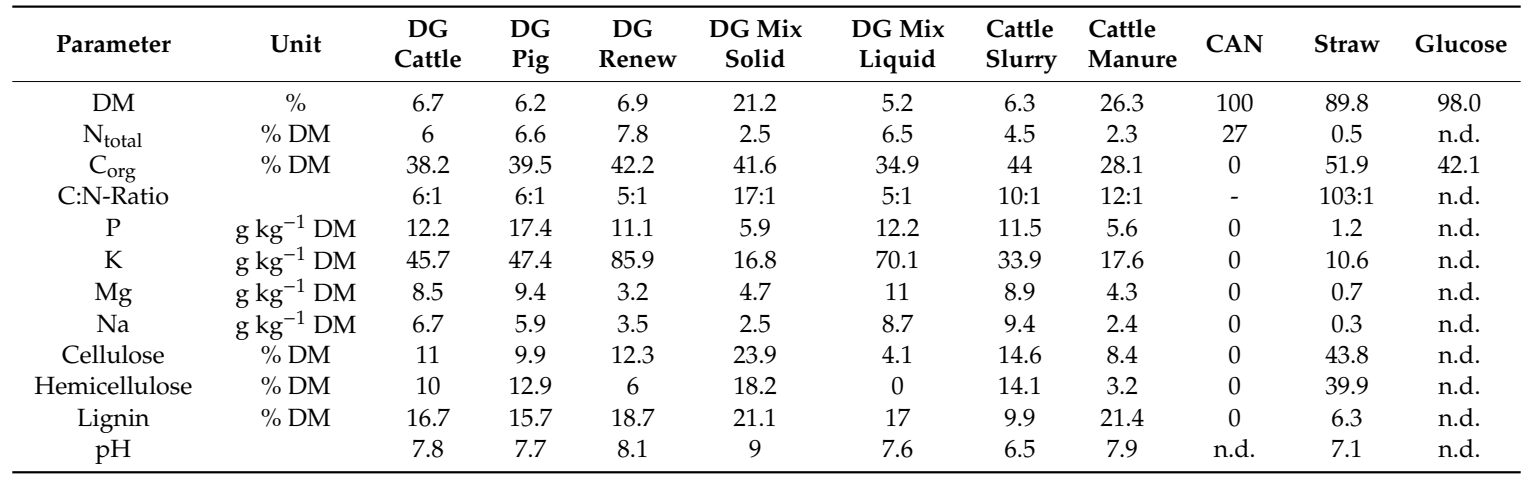


Table 4. Soil texture and chemical properties of the soils used in the soil respiration experiment.

\begin{tabular}{ccccccc}
\hline Soil & Sand (\%) & Silt (\%) & Clay (\%) & $\mathbf{C}_{\text {org }}(\mathbf{\% )}$ & $\begin{array}{c}\mathbf{N}_{\text {total }} \\
(\mathbf{\%})\end{array}$ & $\mathbf{p H}$ \\
\hline Berge & 75.6 & 16.6 & 7.8 & 0.7 & 0.06 & 5.8 \\
Thyrow & 83.1 & 14.2 & 2.7 & 0.4 & 0.05 & 5.4 \\
\hline
\end{tabular}

\subsection{Soil Respiration}

The soil respiration experiment aimed to determine the $C$ conversion rates of different digestates in comparison to conventional organic fertilizer substrates and standard substances. The same organic fertilizers as in the field trial were used (see Table 3) and compared to wheat straw and glucose and a soil only control.

The experiment was carried out in accordance with DIN ISO 16072 [41] under controlled conditions $\left(20 \pm 1^{\circ} \mathrm{C}\right.$, constant water content, no plant growth) in a soil respiration meter (CarbO2Bot ${ }^{\circledR}$ ) from prw electronics (Berlin, Germany). In this device, incubation takes place in $200 \mathrm{~mL}$ vessels, into which $40 \mathrm{~g}$ of soil and an amount of substrate corresponding to $2 \mathrm{~g} \mathrm{~kg}^{-1} \mathrm{C}_{\mathrm{org}}(0.08 \mathrm{~g}$ per vessel $)$ were filled. Released $\mathrm{CO}_{2}$ is collected in an aqueous solution of potassium hydroxide $\left(0.6 \mathrm{~mol} \mathrm{~L}^{-1}\right)$. The absorption of $\mathrm{CO}_{2}$ reduces the electrical conductivity of the $\mathrm{KOH}$ solution. The conductivity was recorded cumulatively every hour over a period of 178 days. The $\mathrm{CO}_{2}$ release was then calculated from the change in conductivity, taking into account a correction derived from empty vessels with the following formula:

$$
\begin{gathered}
\mathrm{CO}_{2}(\mathrm{mg})=1-((\text { conductivity test vessel }) /(\text { conductivity empty vessel })) \times \mathrm{CO}_{2} \text { Coeff. } \\
\times \text { molarity lye }(\mathrm{mol}) \times \text { volume lye }(\mathrm{mL})
\end{gathered}
$$

The $\mathrm{CO}_{2}$ coefficient $\left(\mathrm{CO}_{2}\right.$ Coeff.) is calculated according to Chapman [42] at 39.76.

Two different soils were used in the experiment: (a) Soil from the untreated control plots of the field trial ("Berge") and (b) soil from the research station of the Berlin Humboldt University in Thyrow, Brandenburg, Germany ("Thyrow"). The first one is a loamy sand to sandy loam, the second one is a silty sand with a very low content of organic matter (Table 4). All treatments were replicated four times.

\subsection{Statistical Analysis}

DHA was statistically analyzed with one-way ANOVA followed by Tukey's post hoc test (at $p \leq 0.05$ ) to analyze the significance of differences between the treatments and by two-way ANOVA $(p \leq 0.05)$ to identify the significance and possible interactions of the factor treatment and sampling date. Soil respiration was analyzed with two factor variance analysis to identify differences between treatments and soils. Correlations were determined with Pearson's correlation coefficient. In addition, the soil respiration of digestates, manure, and slurry was visualized using principal component analysis (PCA). Data in figures/tables were calculated as arithmetic means \pm standard deviation (SD). Statistical analysis was conducted using SPSS Statistics Desktop 20.0 for Windows (IBM, Armonk, NY, USA).

\section{Results and Discussion}

\subsection{Dehydrogenase Activity}

Dehydrogenase activity in the field soil was increased by all organic fertilizers (Figure 3). This is in accordance with Makádi et al. [43], who also found that dehydrogenase activity was promoted by digestate application, while catalase and invertase activity was not enhanced by digestates. Other authors also reported an increase in microbial activity after the application of organic materials such as compost and manure [44,45]. It must, however, be noted that on day 0 (before application, or rather 7 months after the last application (see Figure 2)), DHA was not significantly different from the control in all treatments, indicating that the DHA-promoting effects are rather short lived and do not last from one application date to the next. 

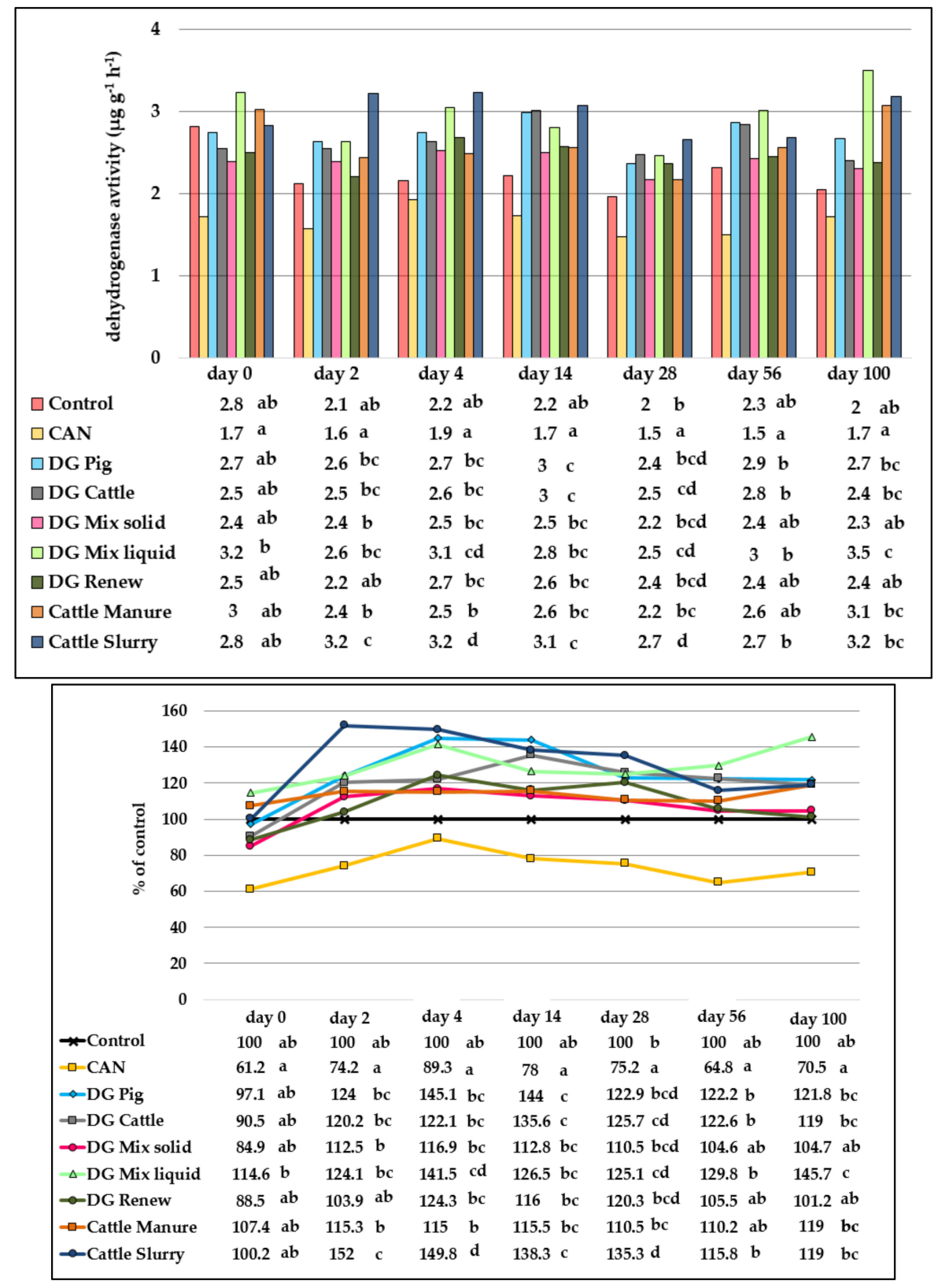

Figure 3. Dehydrogenase activity (DHA) in the field experiment. Bars show absolute values; lines show the percentage of DHA in comparison to the control (control $=100 \%$ ). Different letters mark significant differences between treatments within one column, viz. on the respective day of measurement (Tukey's HSD test, $p \leq 0.05, n=4)$.

The immediate effects after application were greatest and statistically different from the control for DG Pig (day 14), DG Cattle (days 14 and 28), DG Mix liquid (days 4, 7, 28, and 100) and Cattle Slurry (days 2, 4, 7, 14, and 28). These four fertilizers have on average the lowest $\mathrm{pH}(<7.8$; see e.g., Table 3).

Significantly positive correlations were indeed found between the $\mathrm{pH}$ of the soil sample and DHA on five sampling dates and overall (Figure 4). The correlations between $\mathrm{pH}$ and DHA were particularly close before fertilizer application (day 0) or 100 days after application. Apparently, the potential effects of $\mathrm{pH}$ on DHA are temporarily overshadowed after fertilization, e.g., by the availability of degradable organic matter or soil moisture. The $\mathrm{pH}$ was, however, positively correlated to the dehydrogenase activity (higher $\mathrm{pH}=$ higher DHA). A positive correlation between $\mathrm{pH}$ and DHA is reported by other authors as well $[24,46]$. The $\mathrm{pH}$ of the digestate is therefore not a direct indicator of its influence on the 
DHA, as it cannot be stated from this data that digestates with higher $\mathrm{pH}$ necessarily lead to higher soil $\mathrm{pH}$ and higher DHA.
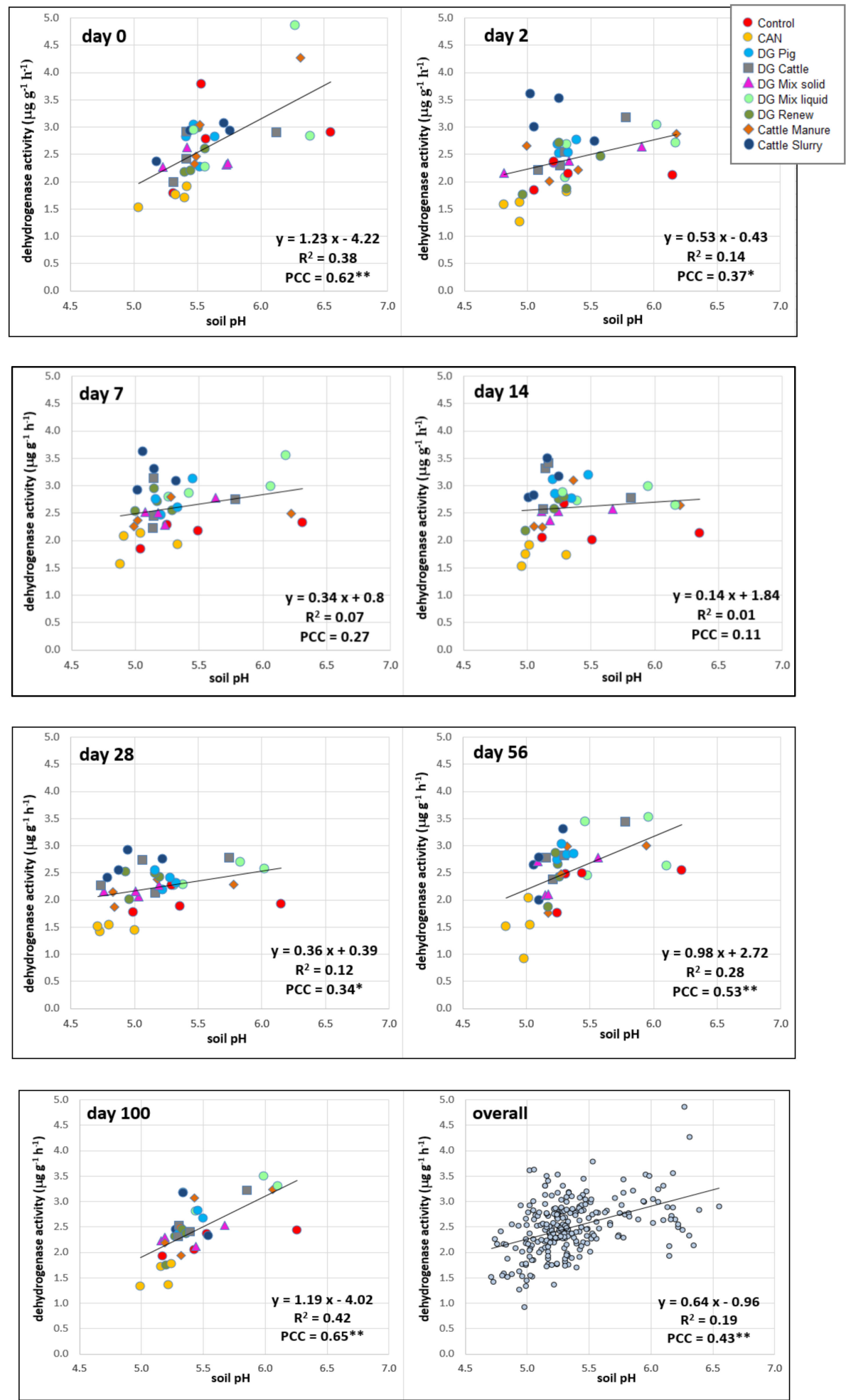

Figure 4. Regressions and Pearson's correlation coefficients (PCCs) for correlations between dehydrogenase activity in the field experiment and the $\mathrm{pH}$ of the soil samples. Significances: ${ }^{*} p<0.05$; ** $p<0.01$ (two-tailed $t$-test). 
Three of the four (DGs Pig, Cattle, and Mix liquid) also provided the highest amount of organic nitrogen via the last application before the measurements (see also Table 2). The other treatments received the same amount of total nitrogen, but a greater proportion of it was given in mineral form.

On those days with maximum temporal distance to the last fertilizer application (day 0 and day 100), dehydrogenase activity was highest in the treatments with DG Mix liquid, suggesting a longer lasting positive effect on microbial activity compared to the other fertilizers. All other treatments did no longer differed significantly from the control on day 100. Treatment DG Mix liquid usually receives no or very low amounts of $\mathrm{N}$ from balancing mineral fertilization because it has a narrow $\mathrm{C}_{\text {org }}: \mathrm{N}$ ratio (see Table 2).

The DHA in the CAN treatment was lower than for all other treatments on all dates, reaching a maximum of $89 \%$ of the untreated control on day 7 after application. In the laboratory experiment, the same trend could be seen (Figure 5). DHA in the CAN treatment reached a maximum of $95 \%$ of the control on day 14 , but accounted, on average, for only $76 \%$ of the control. Nitrate can negatively influence DHA because it serves as an alternative electron acceptor. Fertilizers containing nitrate can thus inhibit dehydrogenase activity for up to at least six months [47]. Some authors claim that this effect can be reversed in the long run when fertilization leads to higher plant biomass production and thereby to more soil organic matter $[48,49]$.
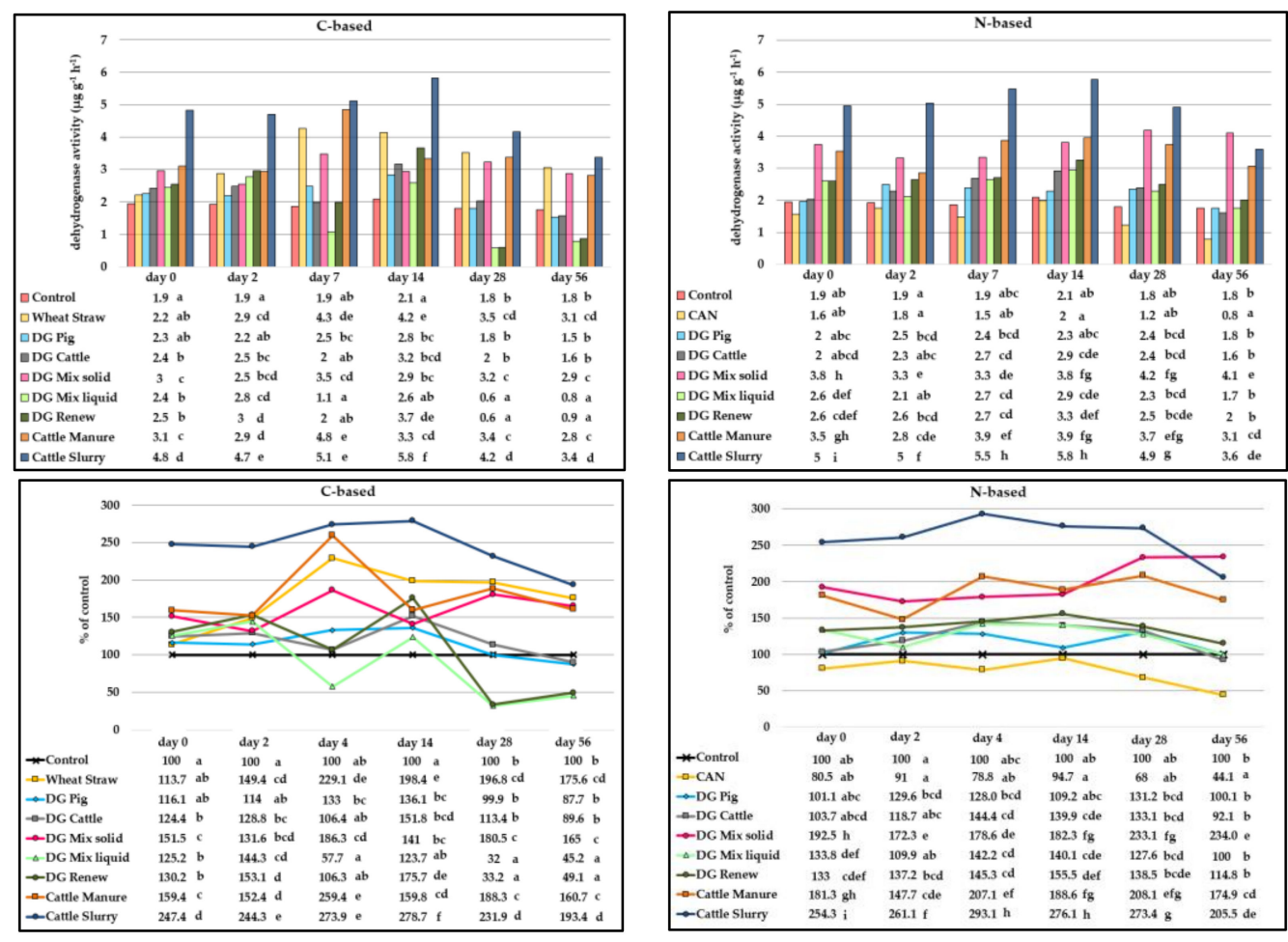

Figure 5. Dehydrogenase activity in the laboratory experiment with a C-based (left figures) and $\mathrm{N}$-based setup (right figures). Bars show absolute values; lines show percentage of DHA in comparison to the control (control $=100 \%$ ). Different letters mark significant differences between treatments within one column, viz. on the respective day of measurement (Tukey's HSD test, $p \leq 0.05, n=3$ ).

A long-term field experiment with annual mineral $\mathrm{N}$ fertilization showed no effect of $\mathrm{CAN}$ on DHA [50]. However, in our field trial, even after five years of fertilization, DHA was still lower in the CAN treatment than in the untreated control. We assume that the frequent application of CAN, usually in six month intervals, might constantly suppress DHA.

The results of the control from the field experiment also show that there is a general fluctuation of DHA over time that is not related to fertilizer application (see Figure 3), but may, for example, be caused by temperature changes or precipitation. A two-way ANOVA showed that the treatment, as well as 
the day of the measurement, had a significant influence on the DHA results ( $p<0.001$, respectively) but that there was no interaction between these two factors $(p=0.681)$. The relative comparison of the treatments as a percentage of the control still demonstrated an overall trend where the application of fertilizers increases DHA in the first 2 to 14 days. It follows a decrease that stretches over a maximum of 80 days. The only exemption from this trend was the DG Mix liquid, which demonstrated a second peak in DHA towards day 100, compared to the control.

In the laboratory experiment, Cattle Slurry generated the highest DHA both in the N-based and in the C-based setup, with values between 193 and 293\% of the control (Figure 5).

In both setups, the four liquid digestates (DGs Pig, Cattle, Mix liquid, and Renew) dropped back to the level at the beginning of the experiment or even beneath that on days 28 and 56. This was not the case for the solid substrates Wheat Straw, Cattle Manure, and DG Mix solid. They also showed a slow decrease in DHA towards the end of the experiment, but still had a much higher DHA on day 56 than on day 0, with values between 161\% (Cattle Manure, C-based) and 234\% (DG Mix solid, N-based) of the control on the last day of the experiment. DG Mix solid, Cattle Manure, and Wheat Straw are the three substrates with the widest C:N ratio (17:1, 12:1, and 103:1, respectively). This might explain the longer-lasting positive effect on dehydrogenase activity compared to the other digestates, especially since comparable results are known from other authors. Rao and Ghai [51], for example, reported a positive correlation between the DHA and nitrogen and organic carbon of the substrate, respectively, with carbon being the most important factor, and Saha et al. [45] also demonstrated a significant positive correlation between DHA and soil carbon content.

In the N-based setup, DHA values were probably connected to differing $C$ inputs, as microbial activity is usually carbon limited [52]. In this setup, most digestates obtained less carbon than slurry, while DG Mix solid and Cattle Manure received more. However, the high DHA values of Cattle Slurry cannot be explained by $\mathrm{C}: \mathrm{N}$ ratios alone.

In accordance with the results from the field experiment, Cattle Slurry application also resulted in higher DHA values in comparison to the digestates in the C-based setup. A DHA-promoting effect of other factors than carbon must exist in Cattle Slurry. Makádi et al. [43] showed that dehydrogenase activity strongly depends on magnesium and sodium.

In the N-based setup, Cattle Slurry was the substrate which brought the highest amounts of magnesium and sodium (1.68 $\mathrm{mg}$ and $1.77 \mathrm{mg}$, respectively) to each vessel. In the C-based setup, however, Cattle Slurry (1.71 mg Na and $1.61 \mathrm{mg} \mathrm{Mg} \mathrm{per} \mathrm{vessel)} \mathrm{was} \mathrm{second} \mathrm{to} \mathrm{DG} \mathrm{Mix} \mathrm{liquid} \mathrm{(1.99} \mathrm{mg}$ Na per vessel) with regard to sodium amounts and fourth behind the digestates DG Mix liquid, DG Pig, and DG Cattle with regard to magnesium (2.52 mg, $1.91 \mathrm{mg}$ and $1.78 \mathrm{mg} \mathrm{Mg}$ per vessel, respectively).

In both setups, the amounts of N, P, and $\mathrm{K}$ and also of cellulose and hemicellulose applied with Cattle Slurry were in the medium range of all substrates, but Cattle Slurry did bring the lowest amounts of lignin to each vessel compared to all the digestates. Microbial activity generally focuses first on labile fractions of carbon that are easier to metabolize and provide energy faster [26]. Lignin, on the other hand, is a water-insoluble, aromatic polymer with a high structural complexity and a high molecular weight that is known to inhibit the enzymatic hydrolysis of plant cell walls and usually requires extracellular biodegradative systems for the initial degradation steps [34,53-55]. Dehydrogenase, as written above, is an integral part of intracellular metabolisms, but does not accumulate outside of cells. High relative lignin contents, therefore, probably reduce the DHA and vice versa. According to Chu et al. [49], DHA is highest when fertilization is balanced and N, P, and K are not deficient. The fact that Cattle Slurry had medium contents of these nutrients in comparison to the other fertilizers may thus add to its DHA-promoting effect.

A two-way ANOVA showed, for both setups, that not only the treatment, but also the date of the measurement, were significant factors and that there was also a significant interaction between treatment and date in both setups $(p<0.001)$. It is known that in the short term, fertilizers, especially with a high proportion of labile organic compounds, promote microbiological activity [16,56]. Stabilization during digestion possibly lowers carbon availability in digestates in comparison to undigested slurry, leading 
to a reduced or delayed positive effect of digestates on microbial activity. In the literature, the stronger effects of slurry fertilization on microbial biomass or activity were frequently reported, but these experiments were usually conducted on the basis of equal nitrogen or ammonia fertilization, a setup in which the digestate treatments typically receive less $C$ in comparison to slurry treatments $[9,57,58]$. However, such experiments do not allow to distinguish if the promoting effect of slurry is based on differing carbon inputs or result from differences in the composition and structure of the organic input. Results from this study indicate that the latter mechanism is also relevant.

\subsection{Soil Respiration}

A high $\mathrm{CO}_{2}$ release rate can be seen in all treatments within the first 20-40 days (Figure 6). After-that, there is a sharp reduction in the $\mathrm{CO}_{2}$ release rate. In the soil with a higher clay content (Berge), the curves of most treatments reach a plateau between day 50 and day 100. With the exception of DG Mix solid and Cattle Slurry, all treatments showed a slower rise in mineralization rates in the soil with less clay (Thyrow), where between 1.2 (Cattle Manure) and 3.3 (Glucose) times more days passed until the treatments reached $80 \%$ of their respective maximum mineralization. In particular, Glucose, Wheat Straw, DG Renew, and DG Pig reached no such clear plateau in the Thyrow soil as in the Berge soil within the duration of the experiment, but had a continuously ascending curve of mineralization.

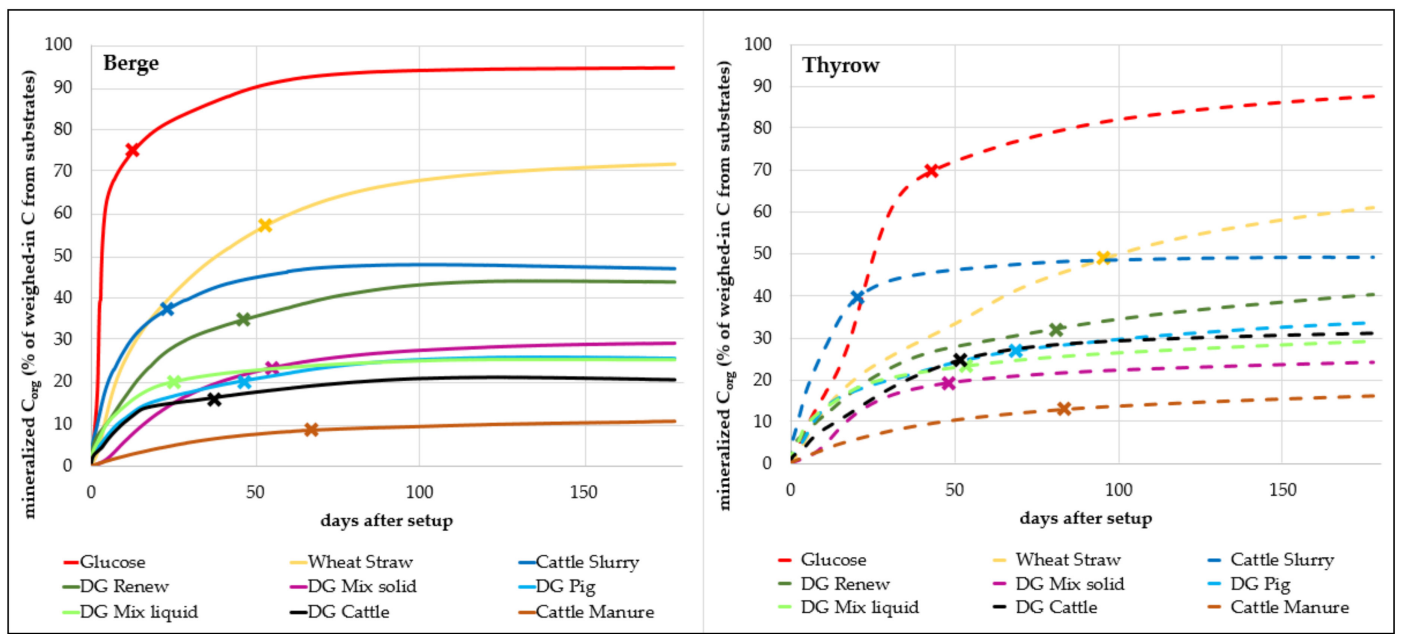

Figure 6. Mineralized proportion of the added organic carbon in the soil respiration experiment depending on the soil type. Soil from Berge with $7.8 \%$ clay, soil from Thyrow with $2.7 \%$ clay. Crosses mark the day on which $80 \%$ of the maximum mineralization was reached. Values shown are mean values from four repetitions.

Of the organic carbon in the digestates, 20 to $44 \%$ was converted to $\mathrm{CO}_{2}$ after 178 days (Table 5). The background $\mathrm{CO}_{2}$ release of the soils differed substantially and was, with $2 \mathrm{mg} \mathrm{CO}$ per $\mathrm{g}$ soil, four times higher in the loamy soil (Berge) than in the sandy soil (Thyrow).

Table 5. Mineralized portion (\%) of the weighed-in carbon after 178 days, depending on the two types of soil from Berge and Thyrow. Different letters within a row mark significant differences between the treatments for each soil (Tukey's HSD test, $p \leq 0.05, n=4$ ).

\begin{tabular}{cccccccccc}
\hline Substrate & $\begin{array}{c}\text { DG } \\
\text { Cattle }\end{array}$ & DG Pig & $\begin{array}{c}\text { DG } \\
\text { Renew }\end{array}$ & $\begin{array}{c}\text { DG Mix } \\
\text { Solid }\end{array}$ & $\begin{array}{c}\text { DG Mix } \\
\text { Liquid }\end{array}$ & $\begin{array}{c}\text { Cattle } \\
\text { Slurry }\end{array}$ & $\begin{array}{c}\text { Cattle } \\
\text { Manure }\end{array}$ & $\begin{array}{c}\text { Wheat } \\
\text { Straw }\end{array}$ & Glucose \\
\hline Berge & $20^{\mathrm{b}}$ & $25^{\mathrm{b}}$ & $44^{\mathrm{c}}$ & $29^{\mathrm{b}}$ & $25^{\mathrm{b}}$ & $51^{\mathrm{c}}$ & $11^{\mathrm{a}}$ & $72^{\mathrm{d}}$ & $95^{\mathrm{e}}$ \\
Thyrow & $31^{\mathrm{abc}}$ & $34^{\mathrm{bcd}}$ & $40^{\mathrm{cd}}$ & $24^{\mathrm{ab}}$ & $29^{\mathrm{abc}}$ & $49^{\mathrm{de}}$ & $16^{\mathrm{a}}$ & $61^{\mathrm{f}}$ & $88^{\mathrm{e}}$ \\
\hline
\end{tabular}

Regarding the maximum percentage of mineralized carbon, the influence of the soil was ambiguous for the treatments. No consistent tendency was recognizable or indicated which soil resulted in the 
higher amount of total mineralized carbon. A two-factor analysis of variances revealed a significant influence of the treatments $(p<0.001)$, but not of the soil type $(p=0.542)$. There was, however, a significant interaction between soil type and treatment $(p<0.001)$.

If one compares the substrates across both soils, the following order of mineralization results (Tukey's HSD test, $p \leq 0.05, n=4$ ):

Cattle Manure $<$ DGs Cattle, Mix solid, and liquid, Pig $<$ DG Renew $<$ Cattle Slurry $<$ Wheat Straw $<$ Glucose

We performed a principal component analysis (PCA) for the organic fertilizers to extract the most important independent factors. Glucose and Wheat Straw were not included. The different samples $(n=56)$, covering seven treatments in four replications and two soils, were characterized by variables describing mineralized carbon at day 178 (\% of weighed-in carbon) and nitrogen, cellulose, hemicellulose, and lignin content. The PCA generated two significant principal components, which explained 48 and $40 \%$ of the variance, respectively (Figure 7). The loadings indicated that nitrogen contents were negatively correlated to hemicellulose and cellulose contents, as described by the first principal component. Mineralized carbon had strong positive loadings and lignin content strong negative loadings for the second principal component, indicating a negative correlation between these variables. Figure 7 shows that DG Mix solid was related to high cellulose and hemicellulose contents, whereas DG Mix liquid was related to high N contents. Hence, it is plausible that the effect of DG Mix solid on DHA was similar to the effect of wheat straw in the C-based trial (Figure 5). Moreover, the effect of DG Mix solid on DHA was comparable to the effect of CAN in the N-based trial (Figure 5). Cattle Manure was highly related to lignin, suggesting that lignin content is the main reason for the low mineralization rate of manure. Digestates with a strong relation to nitrogen, like DGs Mix liquid and Renew, are, on the other hand, more likely to have a high carbon mineralization rate, as is shown in Figure 6. The PCA supports, therefore, the results of the two-factor analysis of variances mentioned before, which had suggested that the treatment is indeed the most important factor influencing carbon mineralization.
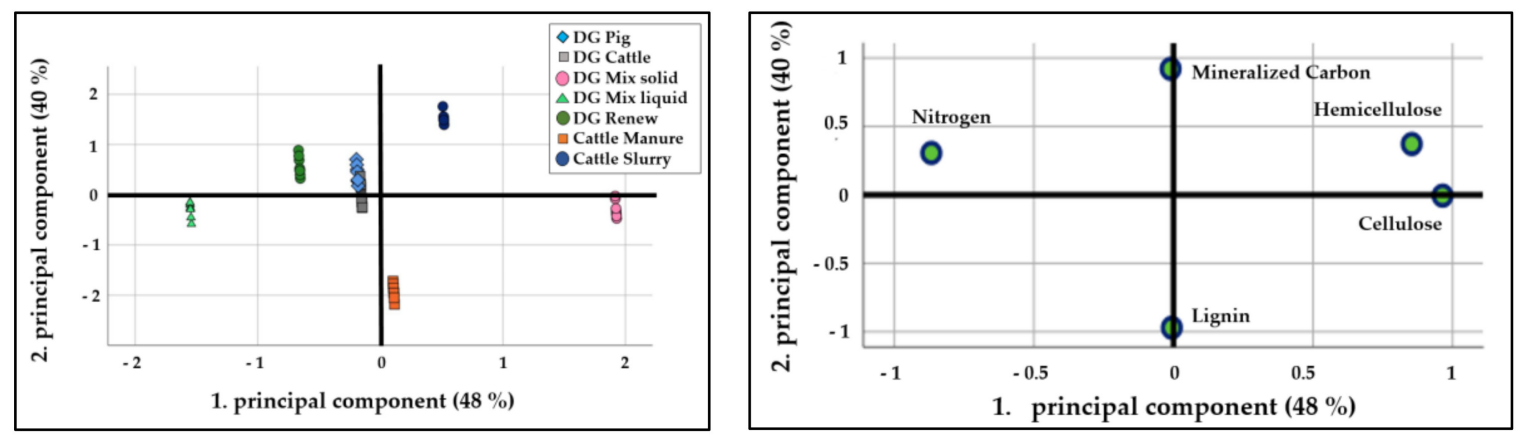

Figure 7. Factor scores (left) and loading plot (right) of the two principal components from different variables describing 56 objects.

Analyses of Pearson's correlation further confirmed the negative relation between lignin content and carbon mineralization (Table 6), which is in accordance with the expectations based on the findings of other authors $[55,59,60]$. Nitrogen, cellulose, and hemicellulose content were not correlated to the maximum mineralized portion of carbon at the end of the experiment, even though in other studies, nitrogen and lignin were equally crucial factors influencing the decomposition and $\mathrm{CO}_{2}$ release of substrates [61]. 
Table 6. Pearson's correlation coefficients and associated significances (two-tailed $t$-test) for correlations between mineralized portion (\%) of the weighed-in carbon after 178 days and amounts of nitrogen, cellulose, hemicellulose, and lignin per vessel in the soil respiration experiment.

\begin{tabular}{ccccccc}
\hline \multirow{2}{*}{ Component } & \multicolumn{2}{c}{ Pearson's Correlation Coefficient } & \multicolumn{3}{c}{ Significance } \\
\cline { 2 - 7 } & Overall & Berge & Thyrow & Overall & Berge & Thyrow \\
\hline N & 0.21 & 0.11 & 0.34 & - & - & - \\
Cellulose & 0.15 & 0.13 & -0.14 & - & - & - \\
Hemicellulose & 0.22 & 0.24 & -0.18 & - & - & - \\
Lignin & -0.82 & -0.78 & -0.90 & $<0.01$ & $<0.01$ & $<0.01$ \\
\hline
\end{tabular}

Several studies have recently shown that residues with a high lignin content decompose slower, but in the long run, more completely than substrates with a low lignin content and may even contribute less to soil organic matter reproduction than those with less lignin [62,63]. In our study, however, the mineralization rates of the lignin-rich substrates reached a stable plateau in at least one of the two soils (the soil with a higher clay content). After 100 days, at the latest, there was no more mineralization of the carbon in the experiment with the substrate. Digestates may, therefore, nonetheless play an important role in soil organic matter reproduction. A high nitrogen content and a narrow N:lignin ratio appear to rather promote the humification of substrates and prevent decomposition $[62,64,65]$. This may be due to the suppression of lignolytic enzymes [66] and a reduced abundance of lignin-degrading microorganisms [67], increased microbial efficiency [68], and/or chemical complexation and the condensation of SOM fractions [64,65].

The results for the soil respiration in a C-based setup for slurry and digestates support the results for DHA in the field and the C-based incubation experiment. Soil respiration was lower for all digestates in comparison to Cattle Slurry. This is in accordance with the literature, as undigested substrates usually have a lower stability in comparison to digestates and slurry is a common substrate for biogas plants $[16,69,70]$. Presumably, microbial digestion processes in the biogas plant exhaust the available organic matter of the substrates and lead to the accumulation of stable organic compounds, such as lignin. The high stability of digestates may have positive effects on the soil organic matter content of soils. However, it should be noted that due to a narrow C:N ratio, digestates usually supply less carbon than other fertilizers if equal amounts of nitrogen are applied.

\section{Conclusions}

Our experiments showed that lignin content is significantly negatively correlated with carbon mineralization and appears to reduce microbial activity, thus confirming hypothesis 1 . Our results therefore indicate a higher potential for SOM reproduction for digestates with high lignin contents. Surprisingly, nitrogen content did not appear to significantly influence the mineralization of carbon.

Results for DHA and soil respiration both indicated that carbon from digestates is less available to microorganisms after soil application than cattle slurry. This effect was visible under laboratory, as well as under field, conditions and is probably related to stabilization processes during digestion.

Hypotheses 2 was could not be confirmed within our experiments: A lasting effect on microbial activity in the soil was not observed in the field trial, where DHA values were back to the level of the unfertilized control within seven months after application, despite the fact that the digestates had been applied to the field twice a year over a period of five years at the time of the measurement. Therefore, digestate application does not appear to have a negative effect on microbial activity even after many years of repeated usage. It could, however, influence the composition of the microbial community [59], which needs to be further investigated.

Hypotheses 3 was only partly confirmed since the soil itself, especially the clay content, appears to influence microbial activity and carbon mineralization rates, even though the maximum ratio of mineralized carbon did not differ clearly between the two soil types. In contrast to the expectations, the mineralization rate was much slower in the soil with less clay, where treatments needed between 
1.2 and 3.3 times longer to reach $80 \%$ of their respective maximum carbon mineralization, at least under otherwise controlled conditions.

Overall, our results showed that digestate application promotes microbial activity for a few weeks, but has no lasting effect on soil microbial activity, even in case of repeated application. In comparison to an untreated control, no negative effects were observed at any point.

Taking this into account, we therefore assume that concerns about a negative effect of digestates on soil fertility are unnecessary as far as they are related to aspects of microbial activity. The digestates' capacity to reproduce SOM needs to be further investigated in long-term experiments without interfering fertilization from other sources. Our results do, however, show that a higher lignin content is one of the major factors determining the mineralization of the organic matter. Regarding the comparison of the organic fertilizers tested here, this would implicate that digestates from plant material only, solid fractions of separated digestates, as well as manure are better suited to reproduce SOM than slurry, liquid fractions of separated digestates, or digestates obtained from pig or cattle slurry. As a consequence, it must be noted that the current practice of some member states of the EU to use only one general factor to calculate the humus reproduction capacity of digestates [71] is not sufficient. Individual factors have to be developed which take into account the digestates' chemical compositions.

This study provides evidence that the parent material and the digestion process in the biogas plant have a marked influence on the quality of the digestate with large implications for soil biological activity, C-turnover, and the reproduction of soil organic matter. However, an overall assessment of the organic inputs tested in this study would require a comprehensive analysis of, i.a., investment, operating expenses, and potential benefits which were not in the scope of this work and need to be addressed in another paper.

Author Contributions: Conceptualization, F.E., K.N.; methodology, F.E., K.N., A.M.; investigation, K.N., M.H., A.M.; writing-Original draft preparation, K.N., C.-L.R.; writing-Review and editing, C.-L.R., T.K., F.E., M.H., A.M.; visualization, C.-L.R., K.N.; supervision, F.E., T.K.; project administration, K.N.; funding acquisition, K.N., F.E., C.-L.R. All authors have read and agreed to the published version of the manuscript.

Funding: This study was funded by the Federal Ministry of Food and Agriculture (former Federal Ministry of Food, Agriculture and Consumer Protection) in Germany under the funding codes FKZ 220-130-10 and FKZ 22012813. We acknowledge support by the German Research Foundation (DFG) and the Open Access Publication Fund of Humboldt-Universität zu Berlin.

Conflicts of Interest: The authors declare no conflict of interest. The funders had no role in the design of the study; in the collection, analyses, or interpretation of data; in the writing of the manuscript, or in the decision to publish the results.

\section{References}

1. Appels, L.; Lauwers, J.; Degrève, J.; Helsen, L.; Lievens, B.; Willems, K.; Van Impe, J.; Dewil, R. Anaerobic digestion in global bio-energy production: Potential and research challenges. Renew. Sustain. Energy Rev. 2011, 15, 4295-4301. [CrossRef]

2. Tambone, F.; Scaglia, B.; D’Imporzano, G.; Schievano, A.; Orzi, V.; Salati, S.; Adani, F. Assessing amendment and fertilizing properties of digestates from anaerobic digestion through a comparative study with digested sludge and compost. Chemosphere 2010, 81, 577-583. [CrossRef] [PubMed]

3. Möller, K.; Müller, T. Effects of anaerobic digestion on digestate nutrient availability and crop growth: A review. Eng. Life Sci. 2012, 12, 242-257. [CrossRef]

4. Maroušek, J.; Bartoš, P.; Filip, M.; Kolář, L.; Konvalina, P.; Maroušková, A.; Moudrý, J.; Peterka, J.; Šál, J.; Šoch, M.; et al. Advances in the agrochemical utilization of fermentation residues reduce the cost of purpose-grown phytomass for biogas production. Energy Sour. Part A Recovery Util. Environ. Eff. 2020, 1-11. [CrossRef]

5. Kolář, L.; Kužel, S.; Peterka, J.; Borová-Batt, J. Utilisation of Waste from Digesters for Biogas Production. In Biofuel's Engineering Process Technology; Bernardes, M.A.d.S., Ed.; IntechOpen: London, UK, 2011. [CrossRef]

6. Stehel, V.; Horák, J.; Vochozka, M. Prediction of institutional sector development and analysis of enterprises active in agriculture. E+M Ekon. A Manag. 2019, 22, 103-118. [CrossRef] 
7. Abubaker, J.; Risberg, K.; Pell, M. Biogas residues as fertilisers-Effects on wheat growth and soil microbial activities. Appl. Energy 2012, 99, 126-134. [CrossRef]

8. Odlare, M.; Pell, M.; Svensson, K. Changes in soil chemical and microbiological properties during 4 years of application of various organic residues. Waste Manag. 2008, 28, 1246-1253. [CrossRef]

9. Abubaker, J.; Cederlund, H.; Arthurson, V.; Pell, M. Bacterial community structure and microbial activity in different soils amended with biogas residues and cattle slurry. Appl. Soil Ecol. 2013, 72, 171-180. [CrossRef]

10. Hupfauf, S.; Bachmann, S.; Fernández-Delgado Juárez, M.; Insam, H.; Eichler-Löbermann, B. Biogas digestates affect crop P uptake and soil microbial community composition. Sci. Total Environ. 2016, 542, 1144-1154. [CrossRef]

11. García-Sánchez, e.; Siles, J.A.; Cajthaml, T.; García-Romera, I.; Tlustoš, P.; Száková, J. Effect of digestate and fly ash applications on soil functional properties and microbial communities. Eur. J. Soil Biol. 2015, 71, 1-12. [CrossRef]

12. Garcia-Sanchez, M.; Garcia-Romera, I.; Cajthaml, T.; Tlustos, P.; Szakova, J. Changes in soil microbial community functionality and structure in a metal-polluted site: The effect of digestate and fly ash applications. J. Env. Manag. 2015, 162, 63-73. [CrossRef] [PubMed]

13. Abubaker, J.; Risberg, K.; Jönsson, E.; Dahlin, A.S.; Cederlund, H.; Pell, M. Short-Term Effects of Biogas Digestates and Pig Slurry Application on Soil Microbial Activity. Appl. Environ. Soil Sci. 2015, 2015, 1-15. [CrossRef]

14. Risberg, K.; Cederlund, H.; Pell, M.; Arthurson, V.; Schnurer, A. Comparative characterization of digestate versus pig slurry and cow manure-Chemical composition and effects on soil microbial activity. Waste Manag. 2017, 61, 529-538. [CrossRef] [PubMed]

15. De la Fuente, C.; Alburquerque, J.A.; Clemente, R.; Bernal, M.P. Soil C and N mineralisation and agricultural value of the products of an anaerobic digestion system. Biol. Fertil. Soils 2012, 49, 313-322. [CrossRef]

16. Johansen, A.; Carter, M.S.; Jensen, E.S.; Hauggard-Nielsen, H.; Ambus, P. Effects of digestate from anaerobically digested cattle slurry and plant materials on soil microbial community and emission of $\mathrm{CO}_{2}$ and $\mathrm{N}_{2} \mathrm{O}$. Appl. Soil Ecol. 2013, 63, 36-44. [CrossRef]

17. Korschens, M.; Weigel, A.; Schulz, E. Turnover of soil organic matter (SOM) and long-term balances-Tools for evaluating sustainable productivity of soils. Z. Fuer Pflanz. Und Bodenkd. (Ger.) 1998, 161, 409-424. [CrossRef]

18. Prays, N.; Dominik, P.; Sanger, A.; Franko, U. Biogas residue parameterization for soil organic matter modeling. PLoS ONE 2018, 13, e0204121. [CrossRef]

19. Maucieri, C.; Barbera, A.C.; Borin, M. Effect of injection depth of digestate liquid fraction on soil carbon dioxide emission and maize biomass production. Ital. J. Agron. 2016, 10, 6-11. [CrossRef]

20. Makádi, M.; Tomócsik, A.; Orosz, V. Digestate: A New Nutrient Source-Review. In Biogas; Kumar, S., Ed.; IntechOpen: London, UK, 2012; pp. 295-310.

21. Cavalli, D.; Corti, M.; Baronchelli, D.; Bechini, L.; Marino Gallina, P. $\mathrm{CO}_{2}$ emissions and mineral nitrogen dynamics following application to soil of undigested liquid cattle manure and digestates. Geoderma 2017, 308, 26-35. [CrossRef]

22. Nkoa, R. Agricultural benefits and environmental risks of soil fertilization with anaerobic digestates: A review. Agron. Sustain. Dev. 2013, 34, 473-492. [CrossRef]

23. Alburquerque, J.A.; de la Fuente, C.; Bernal, M.P. Chemical properties of anaerobic digestates affecting C and $\mathrm{N}$ dynamics in amended soils. Agric. Ecosyst. Environ. 2012, 160, 15-22. [CrossRef]

24. Kumar, S.; Chaudhuri, S.; Maiti, S.K. Soil Dehydrogenase Enzyme Activity in Natural and Mine Soil-A Review. Middle East. J. Sci. Res. 2013, 13, 898-906.

25. Wolinska, A.; Stepniewska, Z. Dehydrogenase Activity in the Soil Environment. In Dehydrogenases; Canuto, R.A., Ed.; IntechOpen: London, UK, 2012; pp. 183-210.

26. Garcia, C.; Hernandez, T.; Costa, F. Potential use of dehydrogenase activity as an index of microbial activity in degraded soils. Commun. Soil Sci. Plant. Anal. 2008, 28, 123-134. [CrossRef]

27. Huang, P.M.; Hardie, A.G. Formation Mechanisms of Humic Substances in the Environment. In Biophysico-Chemical Processes Involving Natural Nonliving Organic Matter in Environmental Systems; Senesi, N., Xing, B., Huang, P.M., Eds.; John Wiley \& Sons, Inc.: Hoboken, NJ, USA, 2009; pp. 41-109. [CrossRef]

28. Ottow, J.C.G. Mikrobiologie von Böden-Biodiversität, Ökophysiologie und Metagenomik; Springer: Berlin, Germany, 2011. [CrossRef] 
29. Trumbore, S.E. Potential responses of soil organic carbon to global environmental change. Proc. Natl. Acad. Sci. USA 1997, 94, 8284-8291. [CrossRef] [PubMed]

30. Blume, H.-P.; Brümmer, G.W.; Horn, R.; Kandeler, E.; Kögel-Knabner, I.; Kretzschmar, R.; Stahr, K.; Wilke, B.-M. Scheffer/Schachtschabel Soil Science, 1st ed.; Springer: Berlin, Germany, 2015.

31. Bermejo Domínguez, G. Agro-Ecological Aspects when Applying the Remaining Products from Agricultural Biogas Processes as Fertilizer in Crop Production. Ph.D. Thesis, Humboldt-Universität zu Berlin, Berlin, Germany, August 2012.

32. Fangueiro, D.; Gusmão, M.; Grilo, J.; Porfírio, G.; Vasconcelos, E.; Cabral, F. Proportion, composition and potential $\mathrm{N}$ mineralisation of particle size fractions obtained by mechanical separation of animal slurry. Biosyst. Eng. 2010, 106, 333-337. [CrossRef]

33. Bahri, H.; Rasse, D.P.; Rumpel, C.; Dignac, M.F.; Bardoux, G.; Mariotti, A. Lignin degradation during a laboratory incubation followed by 13C isotope analysis. Soil Biol. Biochem. 2008, 40, 1916-1922. [CrossRef]

34. Kirk, T.K. Enzymatic "Combustion": The Microbial Degradation of Lignin. Annu. Rev. Microbiol. 1987, 41, 465-505. [CrossRef]

35. Chen, R.; Blagodatskaya, E.; Senbayram, M.; Blagodatsky, S.; Myachina, O.; Dittert, K.; Kuzyakov, Y. Decomposition of biogas residues in soil and their effects on microbial growth kinetics and enzyme activities. Biomass Bioenergy 2012, 45, 221-229. [CrossRef]

36. Franzluebbers, A.J.; Arshad, M.A. Particulate Organic Carbon Content and Potential Mineralization as Affected by Tillage and Texture. Soil Sci. Soc. Am. J. 1997, 61, 1382-1386. [CrossRef]

37. Schulz, E. Einfluss von Bodenart und langjährig differenzierter düngung auf die Akkumulation und Stabilisierung Organischer Bodensubstanz (OBS) in unterschiedlichen Bodenfraktionen. Arch. Agron. Soil Sci. 2000, 45, 365-380. [CrossRef]

38. Rigby, H.; Smith, S.R. Nitrogen availability and indirect measurements of greenhouse gas emissions from aerobic and anaerobic biowaste digestates applied to agricultural soils. Waste Manag. 2013, 33, 2641-2652. [CrossRef] [PubMed]

39. DIN EN ISO 23753-1:2011. Bodenbeschaffenheit-Bestimmung der Dehydrogenaseaktivität in Böden-Teil 1: Verfahren mit Triphenyltetrazoliumchlorid (TTC); Beuth-Verlag: Berlin, Germany, 2011. [CrossRef]

40. DIN ISO 10381-1:2003-08 Bodenbeschaffenheit-Probenahme-Teil 1: Anleitung zur Aufstellung von Probenahmeprogrammen (ISO 10381-1:2002); Beuth-Verlag: Berlin, Germany, 2003. [CrossRef]

41. DIN EN ISO 16072:2011. German Title: Bodenbeschaffenheit_Laborverfahren zur Bestimmung der Mikrobiellen Bodenatmung (ISO 16072:2002); Beuth Verlag: Berlin, Germany, 2011. [CrossRef]

42. Chapman, S.B. A Simple Conductimetric Soil Respirometer for Field Use. OIKOS 1971, 22, 348-353. [CrossRef]

43. Makádi, M.; Tomócsik, A.; Orosz, V.; Bogdányi, Z.; Biró, B. Effect of a biogas-digestate and bentonite on some enzyme activities of the amended soils. Cereal Res. Commun. 2007, 35, 741-744. [CrossRef]

44. Islam, M.R.; Singh Chauhan, P.; Kim, Y.; Kim, M.; Sa, T. Community level functional diversity and enzyme activities in paddy soils under different long-term fertilizer management practices. Biol. Fertil. Soils 2010, 47, 599-604. [CrossRef]

45. Saha, S.; Prakash, V.; Kundu, S.; Kumar, N.; Lal Mina, B. Soil enzymatic activity as affected by long term application of farm yard manure and mineral fertilizer under a rainfed soybean-wheat system in N-W Himalaya. Eur. J. Soil Biol. 2008, 44, 309-315. [CrossRef]

46. Trevors, J.T. Effect of substrate concentration, inorganic nitrogen, $\mathrm{O}_{2}$ concentration, temperature and $\mathrm{pH}$ on dehydrogenase activity in soil. Plant. Soil 1984, 77, 285-293. [CrossRef]

47. Goyal, S.; Chander, K.; Mundra, M.C.; Kapoor, K.K. Influence of inorganic fertilizers and organic amendments on soil organic matter and soil microbial properties under tropical conditions. Biol. Fertil. Soils 1999, 29, 196-200. [CrossRef]

48. Dhull, S.; Goyal, S.; Kapoor, K.; Mundra, M. Microbial biomass carbon and microbial activities of soils receiving chemical fertilizers and organic amendments. Arch. Agron. Soil Sci. 2004, 50, 641-647. [CrossRef]

49. Chu, H.; Lin, X.; Fujii, T.; Morimoto, S.; Yagi, K.; Hu, J.; Zhang, J. Soil microbial biomass, dehydrogenase activity, bacterial community structure in response to long-term fertilizer management. Soil Biol. Biochem. 2007, 39, 2971-2976. [CrossRef]

50. Kautz, T.; Wirth, S.; Ellmer, F. Microbial activity in a sandy arable soil is governed by the fertilization regime. Eur. J. Soil Biol. 2004, 40, 87-94. [CrossRef] 
51. Rao, D.; Ghai, S. Urease und dehydrogenase activity of alkali and reclaimed soils. Aust. J. Soil Res. 1985, 23, 661-665. [CrossRef]

52. Liu, L.; Greaver, T.L. A global perspective on belowground carbon dynamics under nitrogen enrichment. Ecol. Lett. 2010, 13, 819-828. [CrossRef] [PubMed]

53. Grabber, J.H. How Do Lignin Composition, Structure, and Cross-Linking Affect Degradability? A Review of Cell Wall Model Studies. Crop. Sci. 2005, 45, 820-831. [CrossRef]

54. Vikman, M.; Karjomaa, S.; Kapanen, A.; Wallenius, K.; Itavaara, M. The influence of lignin content and temperature on the biodegradation of lignocellulose in composting conditions. Appl. Microbiol. Biotechnol. 2002, 59, 591-598. [CrossRef] [PubMed]

55. Austin, A.T.; Ballare, C.L. Dual role of lignin in plant litter decomposition in terrestrial ecosystems. Proc. Natl. Acad. Sci. USA 2010, 107, 4618-4622. [CrossRef] [PubMed]

56. Annabi, M.; Houot, S.; Francou, C.; Poitrenaud, M.; Bissonnais, Y.L. Soil Aggregate Stability Improvement with Urban Composts of Different Maturities. Soil Sci. Soc. Am. J. 2007, 71, 413-423. [CrossRef]

57. Ernst, G.; Müller, A.; Göhler, H.; Emmerling, C. C and N turnover of fermented residues from biogas plants in soil in the presence of three different earthworm species (Lumbricus terrestris, Aporrectodea longa, Aporrectodea caliginosa). Soil Biol. Biochem. 2008, 40, 1413-1420. [CrossRef]

58. Wentzel, S.; Joergensen, R.G. Effects of biogas and raw slurries on grass growth and soil microbial indices. J. Plant. Nutr. Soil Sci. 2016, 179, 215-222. [CrossRef]

59. Madritch, M.D.; Hunter, M.D. Intraspecific litter diversity and nitrogen deposition affect nutrient dynamics and soil respiration. Oecologia 2003, 136, 124-128. [CrossRef]

60. Tewary, C.K.; Pandey, U.; Singh, J.S. Soil and litter respiration rates in different microhabitats of a mixed oak-conifer forest and their control by edaphic conditions and substrate quality. Plant. Soil 1982, 65, 233-238. [CrossRef]

61. Yanni, S.F.; Whalen, J.K.; Simpson, M.J.; Janzen, H.H. Plant lignin and nitrogen contents control carbon dioxide production and nitrogen mineralization in soils incubated with Bt and non-Bt corn residues. Soil Biol. Biochem. 2011, 43, 63-69. [CrossRef]

62. Stewart, C.E.; Moturi, P.; Follett, R.F.; Halvorson, A.D. Lignin biochemistry and soil N determine crop residue decomposition and soil priming. Biogeochemistry 2015, 124, 335-351. [CrossRef]

63. Cotrufo, M.F.; Wallenstein, M.D.; Boot, C.M.; Denef, K.; Paul, E. The Microbial Efficiency-Matrix Stabilization (MEMS) framework integrates plant litter decomposition with soil organic matter stabilization: Do labile plant inputs form stable soil organic matter? Glob. Change Biol. 2013, 19, 988-995. [CrossRef] [PubMed]

64. Prescott, C.E. Litter decomposition: What controls it and how can we alter it to sequester more carbon in forest soils? Biogeochemistry 2010, 101, 133-149. [CrossRef]

65. Berg, B.; Matzner, E. Effect of $\mathrm{N}$ deposition on decomposition of plant litter and soil organic matter in forest systems. Environ. Rev. 1997, 5, 1-25. [CrossRef]

66. Carreiro, M.M.; Sinsabaugh, R.L.; Repert, D.A.; Parkhurst, D.F. Microbial enzyme shifts explain litter decay responses to simulated nitrogen deposition. Ecology 2000, 81, 2359-2365. [CrossRef]

67. Frey, S.D.; Knorr, M.; Parrent, J.L.; Simpson, R.T. Chronic nitrogen enrichment affects the structure and function of the soil microbial community in temperate hardwood and pine forests. For. Ecol. Manag. 2004, 196, 159-171. [CrossRef]

68. Agren, G.I.; Bosatta, E.; Magill, A.H. Combining theory and experiment to understand effects of inorganic nitrogen on litter decomposition. Oecologia 2001, 128, 94-98. [CrossRef]

69. Arthurson, V. Closing the Global Energy and Nutrient Cycles through Application of Biogas Residue to Agricultural Land-Potential Benefits and Drawback. Energies 2009, 2, 226-242. [CrossRef]

70. Marcato-Romain, C.-E.; Mohtar, R.; Revel, J.-C.; Pouech, P.; Hafidi, M.; Guiresse, M. Impact of anaerobic digestion on organic matter quality in pig slurry. Int. Biodeterior. Biodegrad. 2009, 63, 260-266. [CrossRef]

71. Wiesler, F.; Hund-Rinke, K.; Gäth, S.; George, E.; Greef, J.M.; Hölzle, L.E.; Holz, F.; Hülsbergen, K.-J.; Pfeil, R.; Severin, K.; et al. Application of Organic Fertilisers and Organic Residual Materials in Agriculture; Federal Ministry of Food and Agriculture: Bonn, Germany, 2015.

(C) 2020 by the authors. Licensee MDPI, Basel, Switzerland. This article is an open access article distributed under the terms and conditions of the Creative Commons Attribution (CC BY) license (http://creativecommons.org/licenses/by/4.0/). 